ISSN 0975-3311

UJBM, Vol. 8, No. 2, July - December 2009, pp 46-46

https://doi.org/10.12725/ujbm.15.5

\title{
LEADERSHIP BEHAVIOUR OF THE HEADS OF HIGHER SECONDARY SCHOOLS IN KERALA
}

\author{
Fr. Thomas P.J.* \& G. Visvanathan ${ }^{* *}$
}

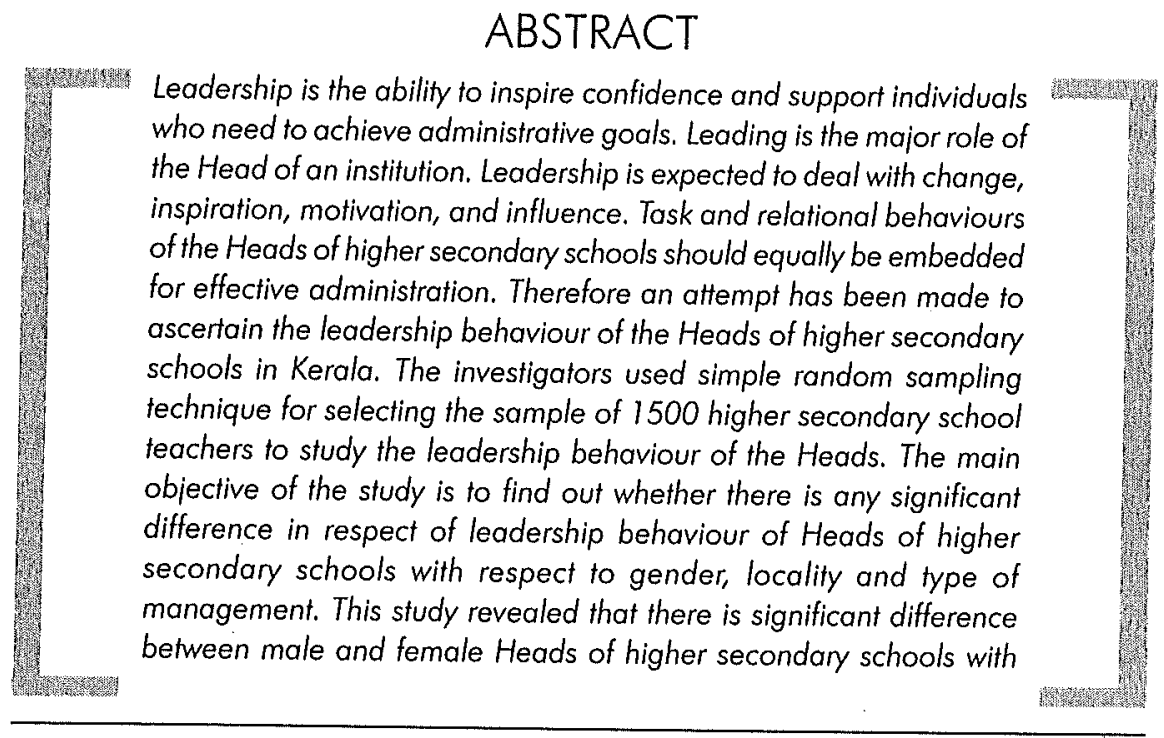

* Lecturer, St.Joseph Training College, Mannanam.

* Dept. of Education, Annamalai University. 
respect to their leadership behaviour and no significant difference is found between rural and urban Heads, government and private higher secondary school Heads with respect to the leadership behaviour. It is found that male heads of higher secondary schools have higher leadership behaviour. Therefore female heads of higher secondary schools should be suitably trained for effective leadership behaviour.

\section{Introduction}

The role and functions of the Heads of schools have been subjected to wide debate and discussions. One of the crucial determinants in school administration is the leadership behaviour of the Heads. These have significant impact on intellectual attainments, educational activities, methods of instruction and functional efficiency. At the same time, these differences have tended to make educational administration very complex and difficult.

\section{Need and Importance of the Study}

Leadership is the ability to inspire confidence and support individuals who need to achieve administrative goals. Leading is the major role of the Head of an institution. Leadership is expected to deal with change, inspiration, motivation, and influence. For an effective leadership both task and relational behaviour need to be embedded among the Heads of higher secondary schools. The challenge for leadership is to investigate the school conditions that are likely to influence student learning outcomes, and examine the relationship between leadership and some school conditions that facilitate positive student learning outcomes (Leithwood and Jantzi, 2000). The principal is a team player, who is to encourage students and teachers. Conger (1999) has suggested that the leader and the context influence each other and that the degree of this influence is dependent on the situation. He argued that contextual variables can be thought of in terms of an outer and an inner school context. Building relationships with the school community was central to the leadership of principals because it was through these relationships that they established and maintained leader legitimacy, and encouraged commitment and effort towards making the goals of shared purposes a reality. 
According to Chemers (2001) the decision to follow depends on the perception of the leader as credible and capable. Thus, a leader must be seen to be trustworthy and competent by followers. The evidence in this study suggests that school principals established and maintained their leadership credibility through the articulation and consistency of their example and actions with shared purposes. Therefore an attempt has been made ascertain the leadership behaviour of the Heads of higher secondary schools in Kerala.

\section{Statement of the Problem}

The problem is entitled "Leadership Behaviour of the Heads of Higher Secondary Schools in Kerala".

\section{Definition of the Terms}

\section{Leadership behaviour}

It refers to the style of functioning characterized by task behaviour and relational behaviour of heads of higher secondary schools.

\section{Heads of Schools}

Heads of schools refer to the principal and headmaster/headmistress of higher secondary schools.

\section{Higher Secondary Schools}

Schools having plus one and plus two courses of Kerala State Syllabus.

\section{Objectives of the Study}

Following were the objectives of the study.

1. To assess leadership behaviour of the Heads of higher secondary schools.

2. To find out the whether there is any significant difference between male and female Heads of higher secondary schools with respect to their leadership behaviour. 
3. To find out the whether there is any significant difference between rural and urban Heads of higher secondary schools with respect to their leadership behaviour.

4. To find out the whether there is any significant difference between private and government Heads of higher secondary schools with respect to their leadership behaviour.

5. To find out the whether there is any significant difference among Heads of higher secondary schools having different years of experience with respect to their leadership behaviour.

\section{Hypotheses of the Study}

The following hypotheses were formulated from the above objectives.

1. Heads of higher secondary schools have poor leadership behaviour.

2. There is no significant difference between male and female Heads of higher secondary schools with respect to their leadership behaviour.

3. There is no significant difference between rural and urban Heads of higher secondary schools with respect to their leadership behaviour.

4. There is no significant difference between private and government Heads of higher secondary schools with respect to their leadership behaviour.

5. There is no significant difference among Heads of higher secondary schools having different years of experience with respect to their leadership behaviour.

\section{Method Adopted in the Study}

In the present study, the investigators employed normative survey method which discovers, describes and interprets what existed in the past and describes deliberatively about the existing status.

\section{Sample}

The investigators used simple random sampling technique for selecting the sample. Adopting this technique, investigators selected 150 higher secondary 
schools from 5 districts in Kerala namely Thiruvananthapuram, Alappuzha, Idukki, Kottayam and Ernakulam. From each school Principal and Headmaster/Head mistress were selected for the assessment of their leadership behaviour. Ten teachers from each school were randomly selected and asked to give their perception of the leadership behaviour of the Heads of higher secondary schools.

\section{Tool Used}

Leadership Behaviour Description Scale (LBDS) was constructed and validated by the investigators to measure leadership behaviour of the Heads of higher secondary schools in Kerala. This questionnaire consists of 38 statements equally distributed to task behaviour and relational behaviour. The teachers of higher secondary schools were asked to give their responses on a five point scale ranging from "Always, Often, Occasionally, Seldom and Never". The scores range from 4-0.

\section{Statistical Techniques}

The obtained data were analyzed using different statistical techniques. The total obtained raw scores, mean and standard deviations were calculated. Then the raw scores were converted into standard scores ( $Z$ scores). Based on $Z$ scores, three categories of leadership behaviour such as poor, moderate and high were computed. The data were further subjected to differential analysis.

\section{Results of the Study}

The results of leadership behaviour of the heads of higher secondary schools in Kerala are given in Table 1.

Table 1 : Showing the distribution of leadership behaviour of the Heads of higher secondary schools

\begin{tabular}{|c|c|c|c|}
\hline Groups & Low & Moderate & High \\
\hline$\%$ & 22 & 50 & 28 \\
\hline
\end{tabular}

From Table 1 shows that among the 300 Heads of higher secondary schools $22 \%$ of Heads of higher secondary schools have low leadership 
behaviour, $50 \%$ of Heads of higher secondary schools have moderate leadership behaviour and $28 \%$ of Heads of higher secondary schools have high leadership behaviour.

Table 2 : Mean and Standard Deviation scores of leadership behaviour of the Heads of higher secondary schools

\begin{tabular}{|c|c|c|c|}
\hline \multirow{2}{*}{ Entire Sample } & $N$ & Mean & S.D \\
\cline { 2 - 4 } & 1500 & 77.80 & 21.41 \\
\hline
\end{tabular}

The arithmetic mean obtained for the scores of the leadership behaviour of the Heads of higher secondary schools assessed by teachers is 77.80 and the Standard Deviation score is 21.41. This shows that the Heads of higher secondary schools have moderate leadership behaviour.

Table 3 : The test of significance ('t'- test) scores of leadership behaviour of the Heads of higher secondary schools

\begin{tabular}{|l|l|c|c|c|l|}
\hline Variables & Sub groups & Mean & S.D. & $\begin{array}{c}\text { ' } f \text { ' } \\
\text { Value }\end{array}$ & $\begin{array}{l}\text { Significance at } \\
0.05 \text { level }\end{array}$ \\
\hline \multirow{2}{*}{ Gender } & Male & 80.90 & 20.43 & 5.09 & Significant \\
& Female & 75.32 & 21.85 & & \\
Locality & Rural & 78.01 & 21.20 & 0.65 & Nol Significant \\
& Urban & 77.17 & 22.03 & & \\
Type of & Government & 77.06 & 21.08 & 0.33 & Not Significant \\
management & Private & 78.09 & 20.57 & & \\
\hline
\end{tabular}

From Table 3 it is found that higher secondary school teachers have assessed their Heads and the following results are arrived. Male Heads of higher secondary schools show higher leadership behaviour than that of their counterparts. Rural Heads of higher secondary schools show higher leadership behaviour than that of their counterparts. Private higher secondary schools Heads show higher leadership behaviour than that of government higher secondary schools Heads. It is found from Table 3 that there is significant difference between leadership behaviour of male and female Heads of higher secondary schools. There is no significant difference is found between rural and urban Heads of higher secondary schools with respect to their leadership behaviour. No significant difference is found between government and private higher secondary schools Heads with respect to their leadership 
behaviour. Hence it is concluded that the Heads of higher secondary schools have moderate level of leadership behaviour.

\section{Discussion}

It is found that male heads of higher secondary schools have higher leadership behaviour. It could be due to the availability of opportunities and rational approaches of men. The fundamental mechanism for leadership is also to be measured in terms of the relationships with individual members of the school community. Leadership in schools is mainly characterised by relationships with individuals, and it is through these relationships a principal is able to establish her/his leadership and encourage teachers to apply their abilities, skills and efforts towards shared purposes. It is important for principals to recognise that effective leadership behaviour are equally embedded with task and relationships. The task behaviour of the principals should be exercised through management practices (Leithwood et al. 1997). For example, walking around the school provides information about what is being taught and the behaviour of students, and at the same time, offers the opportunity to reinforce values and expectations through communication with students and teachers (Leithwood ef al. 1997).

\section{Implications of the Study}

- Context and situations have great role in the formation of leaders. Principals should recognise that context may make leadership behaviour.

- An important implication for a practicing principal is that she/he must know and understand the contextual constraints placed on a school by the internal and external environment.

- Principal must be able to adjust her/his tasks and relational behaviour to ensure that leadership is relevant and assists a school towards positive outcomes.

- It is implied that female heads of higher secondary schools should be suitably trained to become charismatic leaders exhibiting high levels of task and relational behaviour.

- Effective leadership skills should be developed through attending occasional refreshers course on administration. 


\section{Conclusion}

Leading and guiding is the principal role of the Heads of institutions. Effective leader is expected to deal with task and relational behaviour equally be embedded in the administration of higher secondary schools. This study on the leadership behaviour of the Heads of higher secondary school as perceived by the teachers have shown that male Heads of higher secondary schools have higher leadership behaviour. And male and female Heads differ significantly with respect to their leadership behaviour. This could be due to risk taking behaviour and effective management skills of male Heads. Therefore female Heads of higher secondary schools should be suitably trained for effective leadership behaviour.

\section{References}

Awamleh, R., and Gardiner, W. (1999). Perceptions of leader charisma and effectiveness: the effects of content, delivery, and organisational performance. Leadership Quarterly, 10,345-373.

Barnett, K., McCormick, J., and Conners, R. (2000). Leadership behaviour of secondary school principals, teacher outcomes and school learning culture. A paper presented at Australian Association for Research in Education Annual Conference, Sydney, 4.7 December.

Barnett, K., McCormick, J., and Conners, R. (2001). Transformational leadership: panacea, placebo or problem? Journal of Educational Administration, 39, 24-46.

Bass, B. (1985). Leadership and Performance Beyond Expectations. New York: Free Press.

Best, J.W. (2006). Research in Education, New Delhi: Prentice Hall of India Private Limited.

Chemers, M., and Ayman, R. (Eds.) Leadership theory and research: perspectives and directions (pp. 137-166). San Diego: Academic Press.

Conger, J. (1989). The Charismatic Leader: Behind the Mystique of Exceptional Leadership. San Francisco: Jossey-Bass.

Conger, J. (1999). Charismatic and transformational leadership in organisations: an insider's perspective on these developing research streams. Leadership Quarterly, 10, 145 179.

Gideon, B. (2002). Structuring Schools for Teacher Collaboration. Educational Digest, 63, 41-44. 
Harrison, P. T. (1993). The critical elements of effective principal preparation: A Delphi study (effective principals). Dissertation Abstracts International, 54(03), 0753. (University Microfilms No. AAl9322195)

Leithwood, K., and Jantzi, D. (2000). The effects of transformational leadership on organisational conditions and student engagement with school. Journal of Educational Administration, 38, 112-129. 